Jurnal Zarah, Vol. 5 No. 2 (2017), Halaman 44-47

\title{
PENGEMBANGAN MODUL AJAR KIMIA UNSUR BERBASIS INKUIRI TERBIMBING FASE DEVELOPMENT UNTUK MAHASISWA PENDIDIKAN KIMIA
}

\author{
Nina Adriani* \& Friska Septiani Silitonga \\ Prodi Pendidikan Kimia, FKIP UMRAH \\ e-mail korespondensi: nina.adriani@yahoo.com
}

\begin{abstract}
ABSTRAK
Pembelajaran kimia merupakan salah satu pembelajaran yang memerlukan keterampilan dalam memecahkan masalah-masalah ilmu kimia berupa teori, konsep, hukum, dan fakta. Untuk menguasai suatu mata kuliah diperlukan berbagai sarana atau pun alat berupa bahan ajar guna mempermudah proses belajar mengajar, salah satu hal yang penting adalah modul ajar. Tujuan penelitian ini adalah: 1) mengembangkan modul ajar kimia unsur berbasis inkuiri terbimbing pada mahasiswa pendidikan kimia , 2) menguji validitas dari modul kimia unsur yang dikembangkan. Penelitian ini merupakan penelitian dan pengembangan yang dilakukan dengan menerapkan model pengembangan ADDIE tetapi hanya pada tahap pendefinisian, perancangan dan pengembangan modul ajar. Pengumpulan data dilakukan dengan menggunakan instrumen validasi. Pengembangan modul ajar kimia unsur berbasis inkuiri terbimbing dalam pembelajaran kimia dapat meningkatkan keaktifan dan kemampuan yang dimiliki oleh peserta didik untuk mencari dan menyelesaikan permasalahan secara sistematis, logis, dan analitis pada mahasiswa Program Studi Pendidikan Kimia.
\end{abstract}

Kata kunci: modul ajar, kimia unsur, inkuiri terbimbing

\section{PENDAHULUAN}

Pembelajaran kimia merupakan salah satu pembelajaran yang memiliki karakteristik tersendiri dan memerlukan keterampilan dalam memecahkan masalah-masalah ilmu kimia yang berupa teori, konsep, hukum, dan fakta. Salah satu tujuan pembelajaran ilmu kimia adalah agar mahasiswa memahami konsep-konsep kimia dan saling keterkaitannya serta penerapannya baik dalam kehidupan sehari-hari maupun teknologi. Oleh sebab itu, mahasiswa diharapkan mampu memahami dan menguasai konsep-konsep kimia.

Konsep-konsep kimia ini berkaitan erat dengan unsur-unsur yang ada di sekitar kita.

Apabila disebutkan satu per satu akan sangat sulit karena saat ini telah ditemukan kurang lebih 118 unsur. Untuk mempelajari tiap-tiap unsur, pembahasannya sangat kompleks karena sifat-sifat unsur bervariasi antara satu dengan yang lainnya dan jika kita mempelajari satu demi satu alangkah sulitnya. Unsur-unsur tersebut perlu dikelompokkan supaya mudah dalam mempelajarinya dan dibentuklah kimia unsur yang dipelajari dalam mata kuliah kimia unsur.

Untuk menguasai suatu mata kuliah diperlukan berbagai sarana atau pun alat berupa bahan ajar guna mempermudah proses belajar 
mengajar. Salah satu hal yang penting adalah modul ajar, yang berguna untuk membantu mahasiswa dalam memahami materi serta praktek yang akan dipelajari dalam mata kuliah tertentu. Modul ajar merupakan satuan program belajar mengajar yang terkecil yang dapat dipelajari oleh peserta didik secara mandiri atau diajarkan oleh siswa kepada diri sendiri (selfinstructional) (Winkel,2009:9). Modul ajar kimia unsur yang lebih variatif, inovatif dan praktis tentu akan sangat membantu mahasiswa prodi pendidikan kimia UMRAH dalam memahami mata kuliah di bidang ilmu kimia.

Indikator dari keberhasilan tenaga pendidik dalam proses pembelajaran adalah dengan terjadinya perubahan sikap atau pengetahuan dari peserta didik yang telah mengalami proses pembelajaran. Metode pembelajaran yang dapat mengaktifkan siswa di dalam proses pembelajaran adalah dengan menggunakan metode penemuan (discovery) atau penyelidikan (inquiry). Model pembelajaran inquiry ini lebih menekankan pada kegiatan pembelajaran yaitu proses berpikir secara kritis dan analisis untuk menemukan sendiri jawaban dari masalah yang ditanyakan (Sanjaya,2008:41).

Wallace dan Metz (dalam Bilgin,2009:1041) mengemukakan bahwa hal yang penting di dalam penerapan pembelajaran inkuiri terbimbing yaitu peserta didik yang berperan sebagai problem solving dari masalah yang diberikan dan tenaga pendidik sebagai pembimbingnya.

Pada penelitian yang relevan seperti Jannah dkk (2012:60) menyatakan bahwa perangkat pembelajaran berpendekatan karakter melalui inkuiri terbimbing mampu meningkatkan penguasaan pada materi IPA. Zehra Ozdilek (2009:37) berdasarkan hasil penelitiannya menyatakan bahwa metode pengajaran inkuiri terbimbing berbasis temuan kualitatif dan kuantitatif menunjukkan keberhasilan dan efektif di dalam meningkatkan hasil belajar siswa yang ditunjukkan dari hasil post tes yang lebih tinggi dari hasil pre tes. Selanjutnya Rizqi dkk (2013:205) dari hasil penelitiannya menunjukkan bahwa modul IPA terpadu berbasis pendidikan karakter layak dan efektif diterapkan dengan skor mencapai 3,54 dan sesuai dengan kriteria layak menurut BSNP.
Berdasarkan latar belakang tersebut, penelitian ini dilakukan dengan tujuan untuk mengembangkan modul ajar kimia unsur variatif, inovatif dan praktis dalam pembelajaran kimia untuk mahasiswa pendidikan kimia.

\section{METODE PENELITIAN}

Penelitian ini dilaksanakan di ruang kelas Program Studi Pendidikan Kimia, Fakultas Keguruan dan Ilmu Pendidikan, Universitas Maritim Raja Ali Haji kampus Senggarang, dan penelitian ini dimulai pada bulan Mei September 2017. Penelitian yang dilakukan termasuk penelitian pengembangan (research and development/R\&D dengan menggunakan jenis model pengembangan ADDIE. Hal yang menjadi latar belakang dalam memilih model ADDIE sebagai model pengembangan dikarenakan tahapan-tahapannya sederhana, dan sangat sesuai untuk model inkuiri terbimbing. Model ADDIE menurut Molenda di dalam Zaman dkk (2012:4) memiliki lima tahapan, yaitu (A)nalysis, (D)esign, (D)evelopment, (I)mplementation, dan (E)valuation, tetapi dalam artikel ini hanya sampai tahap pengembangan saja.

Pada tahap analisis dimaksudkan untuk mengidentifikasi masalah dan analisis kebutuhan untuk melakukan pengembangan modul ajar berbasis inkuiri. analisis ini berupa analisis kurikulum seperti Standar Kompetensi (SK), Kompetensi dasar (KD), tujuan dan indikator melalui silabus. Analisis kebutuhan mahasiswa dalam kebutuhannya terhadap modul ajar melalui angket yang disebar kepada 40 orang mahasiswa yang telah menyelesaikan mata kuliah kimia unsur. Analisis materi dan pendalaman materi juga dilakukan terhadap materi kimia unsur.

Selanjutnya tahap perancangan dilakukan bertujuan untuk merancang modul pembelajaran kimia unsur berbasis inkuiri terbimbing yang sesuai dengan tujuan dan indikator yang telah ditetapkan sebelumnya. Tahap pengembangan dimulai dengan validasi modul ajar kimia unsur berbasis inkuiri terbimbing yang dilakukan oleh ahli, kemudian modul ajar tersebut direvisi kembali dan setelah dinyatakan layak akan dilakukan uji coba.

Instrumen yang digunakan dalam penelitian yaitu instrumen validitas berupa 
angket yang diberikan kepada ahli materi untuk menilai rancangan dari desain pembelajaran dan modul ajar berbasis inkuiri terbimbing. Aspek penilaian materi modul ini diadaptasi dari komponen penilaian aspek kelayakan isi dan penyajian bahan ajar oleh Badan Standar Nasional Pendidikan (BSNP) serta aspek inkuiri terbimbing.

\section{HASIL PENELITIAN DAN PEMBAHASAN}

Pada tahap analisis sudah dijabarkan tentang Standar Kompetensi (SK), Kompetensi dasar (KD), tujuan dan indikator melalui silabus. Analisis kebutuhan mahasiswa dilakukan dalam bentuk angket sebanyak 20 butir soal yang disebarkan kepada 40 mahasiswa yang telah mengambil mata kuliah kimia unsur. Hasil analisis ini menggunakan skala angka dari 1-4 yaitu :

$1=$ Tidak pernah/tidak ada

$2=$ Jarang

$3=$ Sering

$4=$ Selalu

Melalui hasil angket menunjukkan beberapa butir soal yang hasilnya signifikan seperti tidak adanya modul ajar untuk pembelajaran mata kuliah kimia unsur dengan nilai 1. Nilai 1.45 dan 1.15 terhadap butir soal mengenai tidak adanya bahan ajar lainnya seperti video dan alat peraga serta tidak adanya praktikum.

Selanjutnya nilai 3.5 terhadap butir soal bahwa mahasiswa membutuhkan modul ajar dalam membantu pembelajaran kimia unsur. Nilai 3.9 juga dihasilkan melalui butir soal bahwa mahasiswa menginginkan modul ajar kimia unsur yang dapat meningkatkan keaktifan melalui model pembelajaran inkuiri terbimbing. Dari beberapa nilai dari hasil angket tersebut menunjukkan bahwa perlunya dikembangkan modul ajar dalam meningkatkan pembelajaran kimia.

Langkah selanjutnya adalah tahap perancangan modul sesuai dengan silabus yang telah ditetapkan sebelumnya. Setelah modul ajar kimia unsur dirancang maka divalidasi oleh ahli materi. Validasi modul ajar ini dilakukan oleh dua orang validator yaitu dosen pendidikan kimia. Angket validasi modul ajar kimia unsur ini diadaptasi dari komponen penilaian aspek kelayakan isi dan penyajian bahan ajar oleh
Badan Standar Nasional Pendidikan (BSNP) serta aspek inkuiri terbimbing.

Data hasil validasi modul berbasis inkuiri terbimbing yang diperoleh, disajikan dengan menggunakan skala Likert yaitu memiliki 4 kriteria yaitu sangat valid, valid, kurang valid, dan tidak valid, selanjutnya ratarata nilai dengan menggunakan rumus menurut Muliyardi (2006:24):

$$
\mathrm{R}=\frac{\sum_{\mathrm{j}=1}^{\mathrm{n}} \mathrm{Vij}}{\mathrm{nm}}
$$

dengan, $\mathrm{R}=$ rata-rata nilai dari validator

$\mathrm{Vij}=$ skor hasil penilaian validator ke-j

terhadap kriteria $\mathrm{i}$

$\mathrm{n}=$ banyaknya validator yang menilai

$\mathrm{m}=$ banyaknya kriteria

Menurut Sudjana (2005:11), penetapan tingkat validitas ditentukan menurut kriteria berikut ditunjukkan pada Tabel 3.1 berikut.

Tabel 3.1. Kriteria Kategori Tingkat Validitas

\begin{tabular}{lll}
\hline No & Nilai Validasi & Kriteria \\
\hline 1 & $1,00-1,99$ & Tidak valid \\
2 & $2,00-2,99$ & Kurang valid \\
3 & $3,00-3,49$ & Valid \\
4 & $3,50-4,00$ & Sangat valid \\
\hline
\end{tabular}

Melalui angket validasi yang dilakukan oleh dua validator yang mengandung 34 butir jumlah kriteria memberikan hasil nilai $\mathrm{R}=3.18$. berdasarkan tabel kategori tingkat validitas bahwa nilai 3.18 menunjukkan bahwa modul ajar kimia unsur inkuiri terbimbing telah valid untuk dapat digunakan, tetapi perlu direvisi berdasarkan saran dari validator.

\section{SIMPULAN DAN SARAN}

Modul ajar kimia unsur berbasis inkuiri terbimbing menjadi inovasi baru dalam pembelajaran mata kuliah kimia unsur yang diharapkan dapat meningkatkan meningkatkan keaktifan dan kemampuan yang dimiliki oleh peserta didik untuk mencari dan menyelesaikan permasalahan secara sistematis, logis, dan analitis. Hasil validasi dengan nilai 3.18 
menunjukkan modul ajar telah valid untuk digunakan.

\section{UCAPAN TERIMA KASIH}

Ucapan terima kasih disampaikan kepada Direktorat Riset dan Pengabdian kepada Masyarakat (DRPM) Dirjen Penguatan Riset dan Pengembangan Kemenristekdikti yang telah memberikan dukungan finansial terhadap penelitian ini.

\section{DAFTAR PUSTAKA}

Arikunto, S. 2006. Prosedur Penelitian Suatu PendekatanPraktek. Jakarta : Rineka Cipta.

Bilgin, I. 2009. The Effects of Guided-Inquiry Instruction Incorporating a Cooperative Learning Approach on University Students' Achievement of Acid and Bases Concepts and Attitude. Scientific Research and Essay, 4(10):1038-1046.

Jannah, M., Sugianto, dan Sarwi. 2012. Pengembangan Perangkat Pembelajaran Berorientasi Nilai Karakter melalui Inkuiri Terbimbing Materi Cahaya pada Siswa Kelas VIII Sekolah Menengah Pertama. Journal of Innovative Science Education, 1(1):60.
Muliyardi. 2006. Pengembangan Model Pembelajaran Matematika Menggunakan Komik di Kelas 1 Sekolah Dasar. Disertasi. Universitas Negeri Surabaya. Surabaya

Ozdilek, Z., Bulunuz. 2009. The Effect of a Guided Inquiry Methodon Pre-service Teachers' Sciene Teaching Self Efficacy Beliefs. Journal of Turkish Science Education, 6(2): 24-42

Rizqi, A. M., Parmin, Nurhayati, S. 2013. Pengembangan Modul IPA Terpadu Berkarakter Pemanasan Global untuk Siswa SMP/MTs. Unnes Science Education Journal, 2(1): 203-208

Sanjaya, W. 2008. Strategi Pembelajaran Berorientasi Standar Proses Pendidikan. Jakarta: Prenada Media Grup

Sudjana, N. 2005. Metode Statistika. Bandung: Tarsito

Zaman, M. Q., Sukirman, Nurussa'adah. 2012. Pengembangan Multimedia Pembelajaran Menggunakan Macromedia Flash Professional pada Mata Pelajaran Fisika. Indonesian Journal of Curriculum and Educational Technology $\quad$ Studies. $1(1): 3$ 